\title{
Kolorektal kanserde IncRNA DPP10-AS1 ekspresyonu tümör baskılayıcı ve tümör mikro çevresinde metabolit transportuyla ilişkili olabilir mi?
}

\author{
Could IncRNA DPP10-AS1 expression in colorectal cancer be associated with tumor suppressor and \\ metabolite transport in the tumor microenvironment?
}

\author{
(D) Gülper NACARKAHYA' ${ }^{1}$, DCem HOROZOĞLU² \\ ${ }^{1}$ Gaziantep Üniversitesi Tıp Fakültesi, Tıbbi Biyoloji Anabilim Dalı, Gaziantep \\ ${ }^{2}$ Biruni Üniversitesi Tıp Fakültesi, Tıbbi Biyokimya Anabilim Dalı, İstanbul
}

\begin{abstract}
Giriş ve Amaç: Onkogen ve tümör baskılayıcı gen ifadeleri başta olmak üzere birçok ribonükleik asit ve proteinle moleküler etkileşimde bulunabilen uzun kodlanmayan ribonükleik asitler solid organ kanserlerinde ilişkilendirilmeye başlanmıştır. Deneysel çalışmalarda Wingless ile ilgili entegrasyon bölgesi/beta-katenin yolağı ile ilişkilendirilen uzun kodlanmayan ribonükleik asit DPP10-AS1'in çalısmamızda kolorektal tümörlerdeki ifadesi ve serum biyobelirteçleriyle olan ilişkisinin incelenmesi amaçlanmıştır. Gereç ve Yöntem: Kolorektal kanser tanılı elli bir olgunun tümör ve tümörsüz çevre dokusuna ait formalinle fikse edilmiş parafine emdirilmiş bloklarından total ribonükleik asit izolasyonu gerçekleştirildi. İzole edilen total ribonükleik asitten uzun kodlanmayan ribonükleik asitlere spesifik c-deoksiribonükleik asit sentezi gerçekleştiridikten sonra DPP10-AS1'e özgü primerler ile gerçek zamanlı polimeraz zincir reaksiyonu ile ekspresyon düzeyi tespit edildi. Ekspresyon düzeyleri olguların serum biyobelirteçleriyle korelasyon yönünden incelendi. Bulgular: Uzun kodlanmayan ribonükleik asit DPP10-AS1'in katlı değişimi tümörsüz çevre dokusunda tümör dokusuna göre yaklaşık 5.7 kat yüksek olduğu tespit edilmiştir ( $p=0.0002$ ). Histopatolojik bulgularla uzun kodlanmayan ribonükleik asit DPP10-AS1 arasında istatistiksel bir farkllık tespit edilmezken, uzak organ metastazı olmayanlarda olanlara göre 1.5 kat yüksek olduğu izlenmiştir $(p>0.05)$. DPP10-AS1 ile albü$\min (r: 403 ; p=0.033)$ ve amilaz $(r: 450 ; p=0.031)$ arasında pozitif korelasyonlar tespit edildi. Sonuç: DPP10-AS1'in tümör baskılayıcı rolü olduğunu, albüminle korelasyonu tümör mikro çevresinde sekonder metabolitlerin transportunda rol oynayabileceğini düşündürmektedir. DPP10-AS1 ile amilaz korelasyonunun literatürde tanımlanan yüksek amilaz düzeylerinin tümör farklılaşması, çoğalması sürecindeki etkisiyle paralel şekilde tümör mikro çevresinin bir yanıtı olarak ifade edilebileceğini düşünmekteyiz.
\end{abstract}

Anahtar kelimeler: Uzun kodlanmayan ribonükleik asit, IncRNA, DPP10-AS1, amilaz, albümin, kolorektal kanser

\section{Giriș}

Kolorektal kanserler dünya genelinde en yaygın üçüncü kanser olup, kanserden kaynaklanan ölümler arasında dördüncü sıradadır. Kansere bağlı ölümlerin ise yaklaşık $\% 10$ 'unu oluşturur (1). Kolorektal kanser etiyopatoloji-

\footnotetext{
Iletişim: Gülper NACARKAHYA

Gaziantep Üniversitesi Tıp Fakültesi, Tıbbi Biyoloji Anabilim Dalı Osmangazi Üniversite Blv., 27410 Şehitkamil/Gaziantep

Tel: +90 3423601200 •E-mail: gulperkoyuncu@gmail.com
}

Background and Aims: Long non coding ribonucleic acid, which can interact with many RNAs and proteins-especially oncogene and tumor suppressor gene expressions-have begun to be associated with solid organ cancers. This study was conducted with the objective to examine the expression of long non coding ribonucleic acid, DPP10-AS1, which is associated with the Wnt/ $\beta$-catenin pathway in experimental studies, in colorectal tumors and its relationship with serum biomarkers. Materials and Methods: Total ribonucleic acid isolation was performed from formalin-fixed paraffin-impregnated blocks of tumor and tumor-free surrounding tissue of 51 patients with colorectal cancer. After specific c-deoxyribonucleic acid synthesis was performed from the isolated total ribonucleic acids to Long non coding ribonucleic acids, the expression level was determined by real-time polymerase chain reaction with primers specific to DPP10-AS1. Expression levels were analyzed in terms of correlation with serum biomarkers of the cases. Results: The fold change in long non coding ribonucleic acid DPP10-AS1 was found to be approximately 5.7 times higher in tumor-free surrounding tissue than in tumor tissue $(p=0.0002)$. While no statistical difference was detected between histopathological findings and long non coding ribonucleic acid, DPP10-AS1, it was observed to be 1.5 times higher in patients without distant organ metastasis ( $p>0.05$ ). Positive correlations were detected between DPP10-AS1 and albumin ( $r: .403 ; p=0.033)$ as well as between DPP10-AS1 and amylase ( $r$. 450; $p=0.031)$. Conclusion: DPP10-AS1 has a tumor suppressive role, and its correlation with albumin suggests that it may play a significant role in the transportation of secondary metabolites in the tumor microenvironment. The results suggests that the correlation between DPP10-AS1 and amylase can be expressed as a response of the tumor microenvironment in parallel with the effect of high amylase levels on tumor differentiation and proliferation, as defined in the literature.

Keywords: Long non coding ribonucleic acid, InCRNA, DPP10-AS1, amylase, albumin, colorectal cancer

sinde; tümör baskılayıcı genler ve deoksiribonükleik asit (DNA) tamir mekanizması genlerini hedef alan mutasyonların etkisiyle beraber artan yaş, beslenme alışkanlıkları, sedanter yaşam, obezite, inflamatuvar barsak hastalıkları

Nacarkahya G, Horozoğlu C. Could IncRNA DPP10-AS1 expression in colorectal cancer be associated with tumor suppressor and metabolite transport in the tumor microenvironment? The Turkish Journal of Academic Gastroenterology 2021;20:162-168. DOI: 10.17941/agd.974118

Geliş Tarihi: 24.07.2021 • Kabul Tarihi: 06.10.2021 
ve sigara gibi birçok faktör bulunmaktadır. Genetik faktörler açısından ise olguların \%70'i sporadik, \%25'i ailesel, \%5 herediter dağılım göstermektedir. Kromozomal kararsızlık, mikro uydu kararsızlığı, Wingless ile ilgili entegrasyon bölgesi (WNT), mitojenle aktive olan protein kinaz (MAPK), fosfoinositid-3 kinaz (PI3K), dönüştürücü büyüme faktörü beta (TGF- $\beta$ ), tümör protein 53 (TP53) genleriyle ilişkili mutasyon ve translokasyonlar literatürde yaygın moleküler mekanizmalardandır. Buna ek olarak, CpG adası metilatör fenotipi (CIMP) gibi epigenetik düzenleyicilerin de karsinogeneze katkı sağladığı literatürde izlenmektedir (2).

Epigenetik düzenleyiciler arasında yer alan uzun kodlanmayan ribonükleik asit (IncRNA) ve mikro ribonükleik asit (miRNA) tipleri gibi kodlanmayan ribonükleik asitler (ncRNA) son dönemlerde birçok kanser tipiyle ilişkilendirilmeye başlanmıştır (2). LncRNA'lar, transkripsiyon, translasyon ve bu mekanizmaların sentez sonrası düzenlenmelerinde rol oynayan 200 nükleotidden büyük transkriptler halinde sentezlenir (3). LncRNA'lar tümör progresyonu, apoptoz ve metastazı gibi kritik birçok süreçte tümör odağı ve mikro çevresinde onkogenik veya tümör süpressör etki gösterebilmektedir $(4,5)$. Onkogenik aktivite gösteren IncRNA'lar yüksek ekspresyonu ile MYC'in onkogenik aktivitesini arttııı veya WNT sinyal yolu üyelerinin ekspresyonlarını düzenleyici etki gösterirken (6), tümör baskılayıcı aktivite gösterenleri ise p53'e bağlı genlerin ekspresyonu başta olmak üzere tümör proliferasyonunu baskılayabilir. Özellikle tümör baskılayıcı IncRNA'ların ekspresyonu azaldığı zaman hücrelerde apoptoza karşı direnç geliştirerek hücre proliferasyonu artar (7).

IncRNA DPP10-AS1, 744 nükleotid uzunluğunda, 2q14.1'de lokalizedir. (8). Düşük DPP10-AS1 ekspresyonunun, ileri tümör nod metaztaz (TNM) evresi, lenf nodu metastazı ve tümör farklılaşması ile ilişkili olduğu bildirilmiştir (9). Kolorektal kanserlerde WNT/ $\beta$-katenin sinyal yolağında ligandın yokluğu durumunda, sitozolik $\beta$-katenin çekirdek proteinler glikojen sentaz kinaz 3b (GSK-3b), adenomatoz polipozis koliden (APC) oluşan bir multiprotein kompleksi tarafından hızlı şekilde fosforile edilir. Ligandın varlığında ise GSK-3b, hücre membran reseptörüne bağlanarak inaktive olur. Bu durumda, fosforile edilmemiş $\beta$-katenin kompleksten salınarak ve nükleusa yer değiştirerek $\beta$-katenin'in c-MYC, siklin-D1 ve CD44 gibi hedef genleri aktive etmek için TCF/LEF transkripsiyon faktörleri ile etkileşime girmesine izin verir (1214). InCRNA DPP10-AS1, $\beta$-katenin nükleer translokasyonunun baskilanması ile WNT/ $\beta$-katenin yolunu inaktive ederek, metalloproteinaz protein doku baskılayıcı-3'ün (TIMP3) ekspresyonunu artııı kolorektal tümörlerin me- tastazını baskılar (15). LncRNA'lar, gen ekspresyonunu kontrol etmek için endojen bir moleküler sünger olarak görev alıp miRNA'ların işlevini düzenler. miR-127-3p, DPP10-AS1'in moleküler hedefleri arasında olup adenilat siklazı (ADCY1) düzenleyerek tümör baskılayıcı etki gösterebilmektedir $(9,16)$.

Kronik hastalık ekseninde kanserde sistemik inflamatuvar yanıtın izlenmesi önem arz etmektedir. Kolorektal tümörlü olgularda tümör rezeksiyonu öncesi veya sonrası dönemde plazma belirteçlerinin izlenmesinin prognostik önemi olduğu çalışmalarda tespit edilmiştir (17-19). Yaptığımız literatür taramalarında IncRNA DPP10-AS1'in deneysel modellerde incelenmesine karşın klinikopatolojik korelasyonlarının değerlendirilmediği dikkatimizi çekmiştir. Oldukça sınırlı bilgi bulunan DPP10-AS1'in kolon ve rektum tutulumu gösteren tümörlerde ve tümör mikro çevresinde düzeyinin tespitini histopatolojik kriterler açsından değerlendirmeyi çalışmamızda amaçladık. Bunun yanı sıra çalışmamı fonksiyonel görevleri iyi karakterize edilmemiş olan IncRNA DPP10-AS1'in kolorektal kanserli olguların plazma proteinleri ve belirteçleriyle olan korelasyonlarını tespit ederek olası potansiyel rolünü açığa çıkarmayı da hedeflemektedir.

\section{GEREÇ ve YÖNTEM}

\section{Çalışma Dizaynı}

2014-2016 yılları arasında kolorektal kanser tanısı almış olgulardan plazma belirteçleri dosyasında bulunan $25 \mathrm{ka}-$ dın, 26 erkek olmak üzere 50 hastanın tümör dokusu ve yapılan patolojik incelemeler sonucunda tümörsüz çevre dokusu örneklerinin formalinde tespit edilmiş parafine gömülü doku bloklarından 5-20 ㅆm kalınlığında kesitler alınarak biyolojik materyal ve klinikopatolojik veriler sağlanmıştır. Retrospektif çalışmamız Gaziantep Üniversitesi Tıp Fakültesi Etik Kurulunun 26.09.2018 tarihli 2018/204 etik kurul kararına binaen, Helsinki deklarasyon prensiplerine uyularak gerçekleştirilmiştir.

\section{RNA İzolasyonu ve cDNA Sentezi}

Parafin blok kesitlerinden RNeasy FFPE (Qiagen 73504, USA) kiti aracılığıly üretici firma protokollerine uygun şekilde total RNA ekstraksiyonu gerçekleştirilmiştir. Elde edilen total RNA örnekleri spektrofotometrik olarak miktar tayini gerçekleştirildikten sonra \% 1 'lik agaroz jel elektroforezi ile 28S, 185 ribozomal alt birimleri tespit edilerek kalite tayini yapılmışır. Kaliteli RNA ekstrakte edilemeyen örnekler için işlem tekrarlanmıştır. Miktarsal olarak eşitlenen total RNA örneklerinden IncRNA'lara özgü tamamlayıc DNA'ya ters transkripsiyonu için PreAMP cDNA Synt- 
hesis kiti (Qiagen 330451, USA) aracılı̆̆ıyla üretici firma protokollerine uygun şekilde cDNA sentezi gerçekleştirildi.

\section{Gerçek Zamanlı Polimeraz Zincir Reaksiyonu (q-PCR)}

DPP10-AS1 için ileri primer 5'- GGACAGGACACACACAGCAT-3', geri primer 5' -TGGAAGGAACAGGGAAGAAA3 ' kullanılarak ve Housekeeping olarak GAPDH için ileri primer 5'- CTCTGCTCCTCCTGTTCGAC-3', geri primer 5'GACCAAATCCGTTGACTCCG -3' kullanılarak QuantiTect SYBR Green PCR (Qiagen 204143) kiti protokollerine uygun şekilde primer bağlanma sıcaklı̆ı $60{ }^{\circ} \mathrm{C}$ olarak q-PCR gerçekleştirildi. Tespit edilen Ct değerleri $2^{-\Delta \Delta c t}$ yöntemi kullanılarak numunelerin DPP10-AS1'in bağı ölçümü (Relative Quantification) hesaplandı.

\section{İstatistiksel Değerlendirme}

IBM SPSS 22. Versiyon kullanılarak tespit edilen katı değişimlerin tümör ve tümörsüz çevre dokusu arasındaki farkları Mann-Whitney U testi aracılığılla tespit edildi. DPP10AS1 ile plazma parametreleri arasındaki korelasyonlar Spearman korelasyon testi aracılığıyla değerlendirilirken, histopatolojik evrelere göre DPP10-AS1 düzeylerinin karşılaştııımasında student t-testi ve Mann-Whitney $U$ testi kullanıldı.

\section{BULGULAR}

LncRNA DPP10-AS1'in katı değişimi tümörsüz çevre dokusunda tümör dokusuna göre yaklaşık 5.7 kat yüksek olduğu tespit edilmiş olup, ilgili veri şekil 1'de gösterilmiştir $(p=0.0002)$. Klinikopatolojik parametrelerde DPP10-AS1 düzeylerinin referans gene göre kaç kat değiştiği tespit edilmiş olup incelediğinde, erken tümör evresinde (T1 + T2) DPP10-AS1 $9.02 \pm 0.001$ (\%17.6) kat, ileri tümör evresinde $(\mathrm{T} 3+\mathrm{T} 4)$ ise $9.22 \pm 0.10(\% 82.4)$ kat olarak izlenmiştir. Benzer şekilde DPP10-AS1 düzeyinin lenf nodu metastazı olanlarda $9.43 \pm 0.17$ (\%43.1) kat, olmayanlarda $8.99 \pm 0.07$ (\%56.9) kat değiştiği gözlemlendi. Uzak organ metastazı olmayanlarda DPP10-AS1 için 9.38 \pm 0.08 (\%94.1) kat, uzak organ metastazı olanlarda ise $6.02 \pm 0.30$ (\%5.9) kat değişim izlendi. Histopatolojik parametrelere göre DPP10-AS1 düzeyleri Şekil 2'de gösterilmiş olup, istatistiksel bir farklılık tespit edilmedi ( $p$ > 0.05).

Hastaların total protein düzeyi $29.18 \pm 6.10 \mathrm{~g} / \mathrm{L}$, albümin $17.82 \pm 2.72 \mathrm{~g} / \mathrm{L}$, amilaz $64.86 \pm 14.23 \mathrm{U} / \mathrm{L}$, bilirübin $1.51 \pm 0.47 \mathrm{mg} / \mathrm{dL}$, C-reaktif protein (CRP) $40.87 \pm 10.91$ $\mathrm{mg} / \mathrm{L}$, globulin $13.57 \pm 2.12 \mathrm{~g} / \mathrm{L}$, kreatin $3.29 \pm 1.11$ $\mathrm{mg} / \mathrm{dL}$ ve prokalsitonin $8.46 \pm 2.26 \mathrm{ng} / \mathrm{mL}$ olarak tespit edildi.

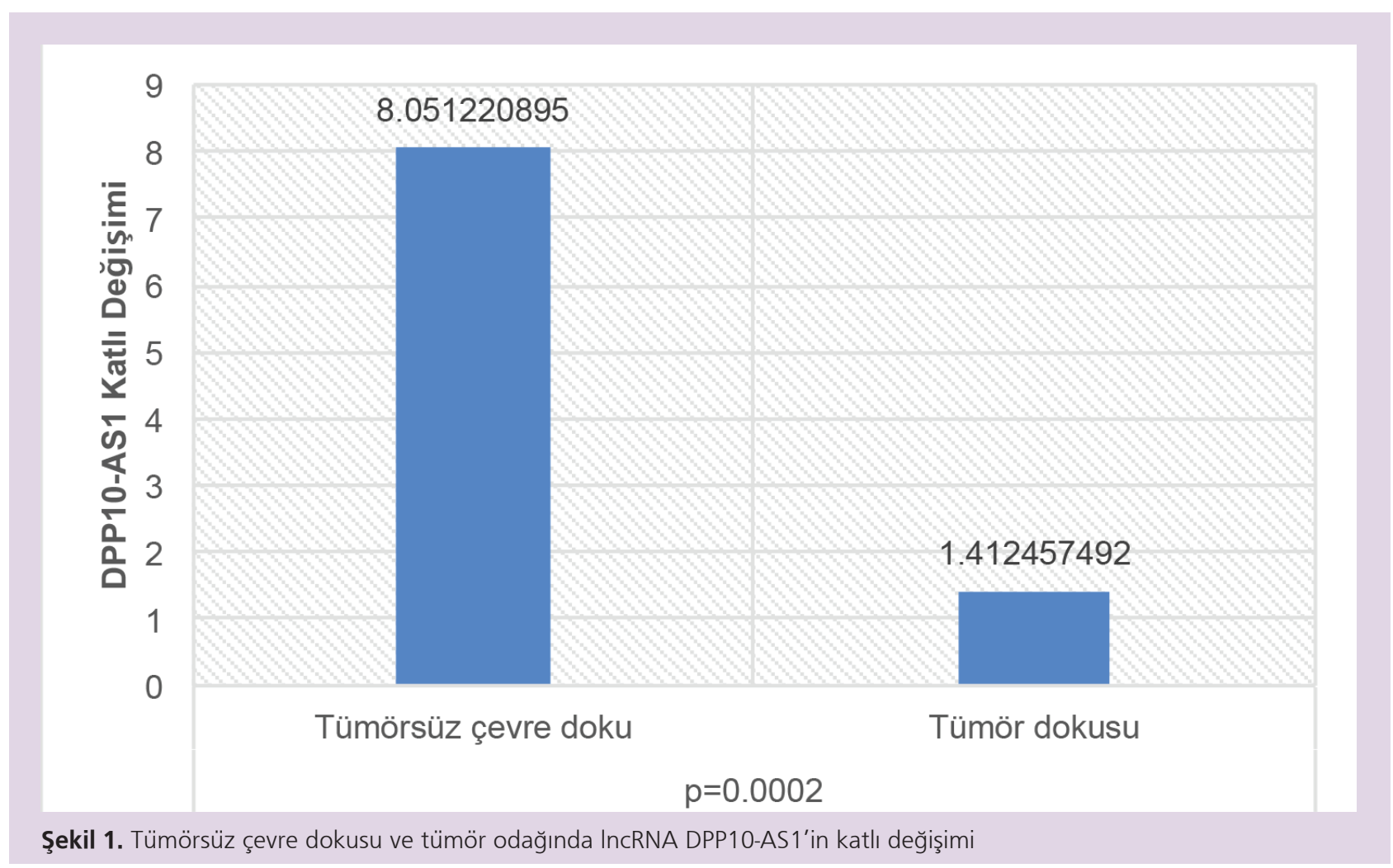




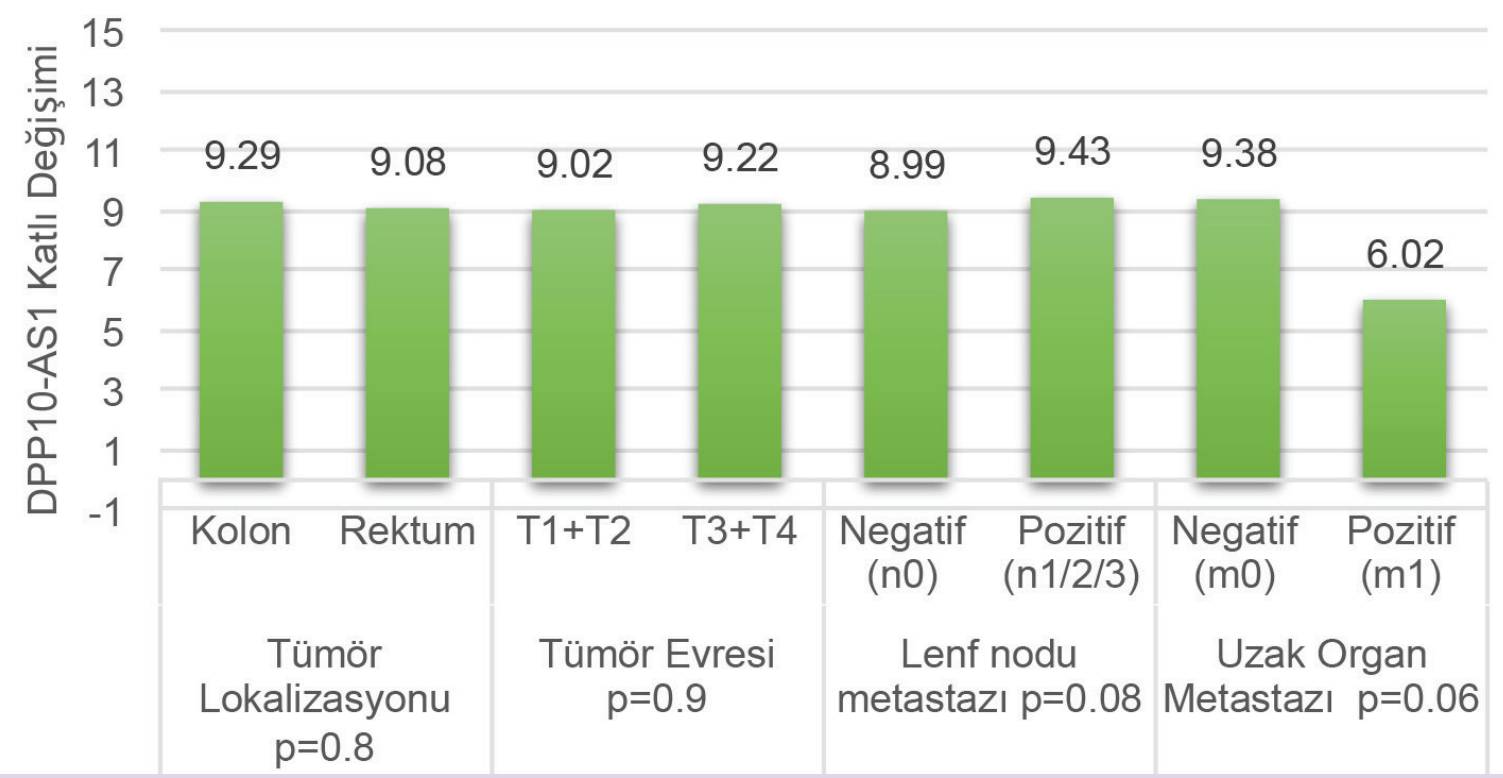

Şekil 2. Tümör histopatolojisine göre IncRNA DPP10-AS1'in katlı değişimi

Tablo 1. DPP10-AS1'in katlı değişimiyle plazma proteinlerinin ve belirteçlerinin korelasyonları

\section{DPP10-AS1 \\ $9.18 \pm 0.85$ \\ (Kat değişimi*)}

\section{Plazma belirteçleri}

Düzey $\pm \mathrm{SE}^{\star *}$

$r$

p

\section{CRP ( $\mathrm{mg} / \mathrm{L})$}

$40.87 \pm 10.91$

$-.227$

.189

Amilaz (U/L)

$64.86 \pm 14.23$

.450

.031

\section{Prokalsitonin $(\mathrm{ng} / \mathrm{mL})$}

$8.46 \pm 2.26$

$-0.26$

.95

\section{Kreatin $(\mathrm{mg} / \mathrm{dL})$}

$3.29 \pm 1.11$

$-.017$

.908

Albümin (g/L)

$17.82 \pm 2.72$

.403

.033

Globulin (g/L)

$13.57 \pm 2.12$

.256

.081

\section{Bilirübin $(\mathrm{mg} / \mathrm{dL})$}

$1.51 \pm 0.47$

.043

Total protein $(\mathrm{g} / \mathrm{L})$

$29.18 \pm 6.10$

$-.085$

.66

CRP: C-reaktif protein.

*Bu değer, her hastanın kendi tümör ifadesinden tümör içermeyen çevre doku ifadesinin çıkarılmasından sonra elde edilen farktan hesaplanan, tüm hastalar için kat değişikliklerinin ortalamasıdır.

**SE: Standart Hata
Dokuda tespit edilen DPP10-AS1 düzeyinin, serum biyobelirteçleri ile olabilecek korelasyonları incelediğinde, albümin ( $\mathrm{r}$ : ,403; $p=0.033$ ) ve amilaz ( $r: 450 ; p=0.031$ ) ile pozitif korelasyonları tespit edildi. Bu veriler Tablo 1'de sunulmuştur.

\section{TARTIȘMA}

Tüm kanser gruplarında olduğu gibi kolorektal kanserler için de IncRNA'lar aracılığıyla gerçekleşebilecek epigenetik değişimlerin saptanması önem arz etmektedir. Bu değişimlerin patofizyolojik mekanizmalarının deşifre edilmesi noktasında, fonksiyonel çalışmalara ek olarak tümör histopatolojisi ve plazma proteinleri gibi bilinen belirteçlerle klinikopatolojik ilişkilendirme çalışmaları potansiyel klinik önemlerinin ortaya çıkmasına yardımcı olacaktır. Onkogenik veya tümör baskılayıcı etkileri klinik çalışmalarda gösterilmiş IncRNA'ların prognostik ve prediktif öneminin dışında terapötik önemi olabileceği son dönemdeki çalışmalarda ortaya konmaktadır. Bu bağlamda IncRNA'ların ekspresyon seviyelerini düzenleyen terapötik yaklaşımlar tümör ve tümör mikro çevresi hücrelerinde malignite aleyhine sonuçlar doğurabilmektedir. Özellikle son birkaç yıl içerisinde antisense oligonükleotidler, nükleusa lokalize primerler ve transkript antagonistleri aracılığıyla farklı solid organ kanseri için dizayn edilmiş hücre kültürü modellerinde yaygın olarak preklinik ve sınırlı sayıda klinik sonuçlar invazyon ve tümör proliferasyonunu kısıtlayabildiğini göstermektedir $(20,21)$. Bu eksende oldukça yeni olan IncRNA'ların fonksiyonel çalışmalarının klinikopatoIojik açıdan irdelendiği çalışmalara intiyaç duyulmaktadır. 
Yaygın etkileri tespit edilmiş IncRNA'ların aksine DPP10AS1 için solid organ kanserlerine ilişkin sınırlı veri literatürde izlenmektedir. Serin proteaz ailesinin üyelerinden birini kodlayan DPP10 geninin intergenik IncRNA's। DPP10-AS1'in DPP10'nun transkripsiyonunu baskılayarak hücre döngüsü ilerlemesinde ve apoptozdan kaçışta kilit rol oynadığı düşünülmektedir. Küçük hücre dışı akciğer kanserli olgularda yüksek DPP10-AS1 düzeyi tespit edilirken TNM ve kötü prognoz ile korelasyonları tespit edilmiştir (8). DPP10-AS1'in küçük hücre dışı akciğer kanserleri için intratümöral yüksek ekspresyonu onkogenik bir IncRNA olabileceği düşüncesini doğurmaktadır.

LncRNA-mRNA etkileşimleri kadar IncRNA-miRNA etkileşimlerinin de patofizyolojik süreçlerde önemli olduğu fonksiyonel çalışmalarda deşifre edilmiştir. DPP10-AS1'in moleküler etkileşenlerinden olan miR-127-3p, ADCY1 aktivitesini negatif düzenlemektedir. Kolorektal kanser kök hücrelerinde DPP10-AS1'in artan ekspresyonunun miR127-3p'yi baskılayarak ADCY1 ekspresyonunu arttırdığı tespit edilmiştir. Bu durum proliferasyonun baskılanması ve apoptoza teşvik edici yönde yanıt oluşturmuştur (9). Kolorektal tümör dokusunda ise tümörsüz çevre dokuya kıyasla düşük gen anlatımı tespit edilmiştir. İntergenik DPP10-AS1'in ana nükleer kodlayıCISI DPP10'un benzer şekilde potasyum kanalını regüle ederek tümör hücresi ve mikro çevresinin düzenlenmesinde aktif rol oynadığı bildirilirken, kolorektal kanserli olguların western blotting sonuçlarına göre negatif olan olgularda kötü prognoz ve düşük sağ kalımla ilişkisi tespit edilmiştir (22-24).

Benzer şekilde bizim çalışmamızda DPP10-AS1'in tümörsüz çevre dokusunda tümör dokusuna göre 5.7 kat yüksek olduğu tespit edilmiştir ( $p=0.0002$ ). Tümör histopatolojisine göre karşılaştırıldığında istatistiksel anlamlı bir değişiklik izlenmemiş sadece uzak organ metastazlı olgularda DPP10-AS1 düzeyi 1.5 kat düşük olarak gözlemlenmiştir ( $p>0.05)$. Bu değişim; ileri evre kanserlerde tümör baskılayıcı etki hakimiyetinin zayıflamasının bir tezahürü olabileceğini düşündürmektedir. Bu veriler küçük hücre dışı akciğer kanserlerinden farklı olarak kolorektal tümörlerde direkt veya indirekt etkileşimlerle DPP10AS1'in tümör baskılayıcı yönde etkisinin olduğu kanaatini doğurmaktadır.

DPP10-AS1'in kolorektal kanser patofizyolojisinde rol oynadığına dair tespit edilen kanıtların dışında klinik önemine ilişkin soru işaretlerini aydınlatabilmek adına olguların akut faz yanıtlarını incelediğimiz zaman albümin (17.82 \pm $2.72 \mathrm{~g} / \mathrm{L}$ ) ile orta düzeyde pozitif korelasyon tespit ettik. Kronik hastalıklarda hastanın inflamatuvar, immün sistem ve nütrisyonel tablosunun iyi bir ayıracı olan albümin dü- zeyleri kanser hastalarında tedavi öncesinde yaygın olarak düşük olarak tespit edilir. Kanserli olgularda düşük albümin düzeyi ile hastanın düşük sağ kalımı arasında paralel bir ilişki çalışmalarda tespit edilmiştir (25). Benzer şekilde CRP/albümin oranının kolorektal kanserli olguların izleminde prognostik öneme sahip olduğu tespit edilmiş olup, yüksek oranlar ile kötü prognoz ilişkilendirilmiştir. Tedavi sonrası dönemde ise CRP/albümin düzeyi kemoterapötik ajana tolerans ve yanıt süreçlerinin değerlendirilmesinde kullanılmaktadır (26-28).

LncRNA DPP10-AS1'in genomik dizisini kodlayan DPP10 için farklı izoformlar tespit edilmiş olup bir serin proteaz ailesi üyesini kodlamasına karşın serin kalıntısının yokluğundan dolayı aktif enzimatik aktivite gösterememektedir. Buna karşın membran proteini olan DPP10'un ekspresyonunun hücre membranında voltaj kanallarının aktivitesini değiş̧tirebildiği çalışmalarda tespit edilmiştir (29). Albüminin onkotik basıncı düzenlemesi ve taşıyıcı protein vazifesi göz önüne alındığında DPP10-AS1'in tümör mikro çevresindeki artışı ile korelasyonu kolorektal tümörlerden açığa çıkan sekonder metabolitlerin tümörsüz çevre dokusu tarafından drene edilmesi fikrini akla getirmektedir. Bu bağlamda albüminle beraber tümör-periferik damar aksında koordineli transport ve düzenlenme sürecinde kilit bir rolünü hedefleyen deney modellerinin tasarlanması uygun bir strateji olacaktır.

DPP10-AS1'in serum belirteçleri ile korelasyonlarını incelediğimizde amilaz ile olan korelasyonu dikkatimizi çekmiştir. Serum amilaz düzeyinin yüksek seyretmesi barsak obstrüksüyonu ve strangülasyonu sebebiyle meydana gelmesine karşın kolorektal kanserlerle direkt ilişkisi literatürde tespit edilmemiştir. Retrospektif bir çalışmada intraduktal müsinöz neoplazi skoruyla serum amilaz ve lipaz düzeylerinin korelasyonu tespit edilmiş olup, normal aralığın dışındaki yüksek veya düşük düzeyler malignite riskiyle ilişkilendirilmiştir (30). Pankreatik ve parotis kökenli alfa amilazın her dokuda spesifik endojen sentezi hala bilinmemektedir. Buna karşın oldukça fazla izoenzimi tanımlanan amilazın pankreastan sonra ikinci sırada duodenumda eksprese edildiği tespit edilmiştir. Bu noktadan hareketle kolon hücre hatlarındaki amilaz ekspresyonunun RNA interferans ile baskılanması sonucunda hücre farklılaşmasının ve çoğalmasının baskılandığı saptanmıştır (31). Çalışmalarda elde edilen bu kanıtlar; amilaz izoformlarının normal düzeydeki kolorektal dokuda varlığının malign tümörlü dokularda da normal sınırların dışına çıktığını göstermektedir. Tümör mikro çevresinde anjiolenfatik faaliyetle ilişkili olabilecek amilaz aktivitesinin damar yatağından periferik dolaşıma katılması serum düzeylerinde değişikliğe sebep olabilir. Küçük örneklemli çalışmamızda 
normal sınırlar içerisinde olduğunu izlediğimiz amilaz düzeyi buna karşın hastalarda DPP10-AS1 ile pozitif korelasyon göstermiştir. Bu durum bize tümör mikro çevresinde meydana gelen birçok değişiklik arasında olan anjiogenez, lenfatik drenaj, mikro metastaz mekanizmalarında DPP10-AS1 ve amilazın görev alabileceğini düşündürmektedir. Epitelyal-mezenkimal geçişler (EMT'ler) sürecinde kompleks bağ dokunun değişimlerinin bir tezahür olabileceğini düşündüğümüz amilazın barsak malign hücrelerinin hücre proliferasyonu ve farklılaşmasıyla ilişkisi Date ve arkadaşlarının 2020 yılında yayınladıkları makalelerinde vurgulanmaktadır (31). Bu bağlantılardan yola çıkarak literatürde sınırlı veri bulunan DPP10-AS1'in kanser biyolojisi açısından rolünü düşündüğümüzde tümör histopatolojisiyle ilişkisinden ziyade tümörün çevre dokusunda yüksek eksprese olduğu izlenmektedir. Bu veriler bize DPP10-AS1'in kolorektal kanserlerde tümör hücresindeki değişimlere katkısından çok daha fazlasını tümör mikro çevresindeki düzenlemelerle sunduğu hipotezini düşündürmektedir.

\section{KAYNAKLAR}

1. Kuipers EJ, Grady WM, Lieberman D, et al. Colorectal cancer. Nat Rev Dis Primers 2015;1:15065.

2. Mármol I, Sánchez-de-Diego C, Pradilla Dieste A, Cerrada E, Rodriguez Yoldi MJ. Colorectal carcinoma: A general overview and future perspectives in colorectal cancer. Int J Mol Sci 2017;18:197.

3. Zhang J, Zhang A, Wang $Y$, et al. New insights into the roles of ncRNA in the STAT3 pathway. Future Oncol 2012; 8:723-730.

4. Jin $Y T, L v L, Y u J G$, et al. Long intergenic non-coding RNA APOC1P1-3 inhibits apoptosis by decreasing $\alpha$-tubulin acetylation in breast cancer. Cell Death Dis 2016;7:e2236.

5. Yuan JH, Yang F, Wang F, et al. A long noncoding RNA activated by TGF-beta promotes the invasion-metastasis cascade in hepatocellular carcinoma. Cancer Cell 2014;25:666-81.

6. Hamilton MJ, Young MD, Sauer S, Martinez E. The interplay of long non-coding RNAs and MYC in cancer. AIMS Biophys 2015;2:794809

7. Gibb EA, Brown CJ, Lam WL. The functional role of long non-coding RNA in human carcinomas. Mol Cancer 2011;10:38.

8. Tian $\mathrm{H}$, Pan J, Fang $\mathrm{S}$, et al. Epigenetic regulation contributes to the oncogenic role of DPP10-AS1 in lung cancer. SSRN 2019;3421596.

9. Liu G, Zhao H, Song Q, et al. Long non-coding RNA DPP10-AS1 exerts anti-tumor effects on colon cancer via the upregulation of ADCY1 by regulating microRNA-127-3p. Aging (Albany NY) 2021;13:9748-65

10. Polakis P. Wnt signaling in cancer. Cold Spring Harb Perspect Biol. 2012;4(5):a008052.

11. Li F, Chong ZZ, Maiese K. Winding through the WNT pathway during cellular development and demise. Histol Histopathol 2006;21:103-24.

12. Polakis P. Wnt signaling and cancer. Genes Dev 2000;14:1837-51.

13. Kikuchi A. Regulation of beta-catenin signaling in the Wnt pathway. Biochem Biophys Res Commun 2000;268:243-8.
Kolorektal kanserli olgu sayısının düşük olması, olguların serum örneklerinde sirküler DPP10-AS1 düzeyinin incelenmemiş olması sınılayıcı faktörlerimizdendir. Çalısmamızın bir sonraki aşamasl; tespit ettiğimiz tümörsüz çevre dokusundaki yüksek ekspresyonun sebebine yönelik immünohistokimyasal çalışmalarla mikro çevre formasyonundaki hücre gruplarının tespiti ve serum örneklerinde DPP10AS1 düzeylerinin tespit edilmesi olacaktır.

Etik Kurul Onayı: Gaziantep Üniversitesi Tıp Fakültesi Etik Kurulunun 26.09.2018 tarihli 2018/204 etik kurul kararına binaen araştırma gerçekleştirilmiştir. Tüm olgulara bilgilendirilmiş onam formu okunarak imzalatılmış olup, araştırma protokolünde Helsinki deklarasyon prensiplerine uyulmuştur.

Çıkar Çatışması Beyanı: Yazarlar herhangi bir çıkar çatışması beyan etmemektedir.

Finansal Destek: Bu çalışma Gaziantep Üniversitesi Bilimsel Araştırma Projeleri birimi tarafından desteklenmiştir. Proje numarasI: TF.ALT.19.19

14. Giles RH, van Es JH, Clevers H. Caught up in a Wnt storm: Wnt signaling in cancer. Biochim Biophys Acta 2003;1653:1-24.

15. Lin J, Tan X, Qiu L, et al. Long noncoding RNA BC032913 as a novel therapeutic target for colorectal cancer that suppresses metastasis by upregulating TIMP3. Mol Ther Nucleic Acids 2017;8:469-81.

16. Ballantyne MD, McDonald RA, Baker AH. IncRNA/MicroRNA interactions in the vasculature. Clin Pharmacol Ther 2016;99:494-501.

17. McMillan DC, Canna K, McArdle CS. Systemic inflammatoryresponse predicts survival following curative resection of col-orectal cancer. Br J Surg 2003;90:215-9.

18. Skinner AC, Steiner MJ, Henderson FW, Perrin EM. Multiple markers of inflammation and weight status: cross-sectional analyses throughout childhood. Pediatrics 2010;125:e801-9.

19. Fox $P$, Hudson $M$, Brown $C$, et al. Markers of systemic inflammation predict survival in patients with advanced renal cell cancer. $\mathrm{Br} \mathrm{J}$ Cancer 2013;109:147-53.

20. Dai M, Chen X, Mo S, et al. Meta-signature LncRNAs serve as novel biomarkers for colorectal cancer: integrated bioinformatics analysis, experimental validation and diagnostic evaluation. Sci Rep $2017 ; 7: 46572$.

21. Arun G, Diermeier SD, Spector DL. Therapeutic targeting of long non-coding RNAs in cancer. Trends Mol Med 2018;3:257-77.

22. Qi SY, Riviere PJ, Trojnar J, Junien JL, Akinsanya KO.. Cloning and characterization of dipeptidyl peptidase 10, a new member of an emerging subgroup of serine proteases. Biochem J 2003;373:17989.

23. Allen M, Heinzmann A, Noguchi E, et al. Positional cloning of a novel gene influencing asthma from chromosome $2 q 14$. Nat Genet 2003;35:258-63.

24. Park HS, Yeo HY, Chang HJ, et al. Dipeptidyl peptidase 10, a novel prognostic marker in colorectal cancer. Yonsei Med J 2013;54:1362-9. 
25. Gupta D, Lis CG. Pretreatment serum albumin as a predictor of cancer survival: a systematic review of the epidemiological literature. Nutr J 2010;9:69.

26. Lu X, Guo W, Xu W, et al. Prognostic value of the Glasgow prognostic score in colorectal cancer: a meta-analysis of 9,839 patients. Cancer Manag Res. 2018;11:229-49.

27. Shibutani M, Maeda K, Nagahara $H$, et al. The significance of the C-reactive protein to albumin ratio as a marker for predicting survival and monitoring chemotherapeutic effectiveness in patients with unresectable metastatic colorectal cancer. Springerplus 2016;5:1798.

28. Tominaga T, Nonaka T, Sumida Yet al. The C-reactive protein to albumin ratio as a predictor of severe side effects of adjuvant chemotherapy in stage III colorectal cancer patients. PLoS One 2016;11:e0167967.
29. Belau F, Metzner K, Christ T, et al. DPP10 is a new regulator of Nav1.5 channels in human heart. Int J Cardiol 2019;284:68-73.

30. Roch AM, Parikh JA, Al-Haddad MA, et al. Abnormal serum pancreatic enzymes, but not pancreatitis, are associated with an increased risk of malignancy in patients with intraductal papillary mucinous neoplasms. Surgery 2014;156:923-9.

31. Date K, Yamazaki T, Toyoda Y, Hoshi K, Ogawa H. $\alpha$-Amylase expressed in human small intestinal epithelial cells is essential for cell proliferation and differentiation. J Cell Biochem 2020;121:1238-49. 